\begin{tabular}{c} 
Volume and Issues Obtainable at Center for Sustainability Research and Consultancy \\
Sustainable Business and Society in Emerging Economies \\
ISSN: $2708-2172$ (E): 2708-2504 \\
Volume 2: Issue 2 December 2020 \\
Journal homepage: $\underline{w w w . p u b l i s h i n g . g l o b a l c s r c . o r g / s b s e e}$ \\
\hline
\end{tabular}

\title{
Assessment of Sustainable Development in Apparel Value Chains
}

\author{
${ }^{1}$ Hina Maryam Binte Zikria, ${ }^{2}$ Muniza Irfan, ${ }^{3}$ Farhat Umar \\ ${ }^{1 \& 2}$ Bachelor of Business Administration in Supply Chain from DHA Suffa University, Karachi, \\ Pakistan, maryamhina83@gmail.com; irfan.muniza@yahoo.com \\ ${ }^{3}$ Senior Lecturer \& Director Corporate Social Responsibility at DHA Suffa University, Karachi, \\ Pakistan, farhat.umar@dsu.edu.pk
}

\begin{tabular}{l}
\hline ARTICLE DETAILS \\
\hline History: \\
Revised format: November, \\
2020 \\
Available Online: December, \\
2020
\end{tabular}

Keywords:

Sustainable Development

Goals, Green Marketing

Strategy, Global Reporting

Initiative, Sustainable

Textiles

JEL Classification:

$M 1, M 2$

\begin{abstract}
Inspired by the United Nation's Sustainability Development goals for responsible consumption and production, this final year two-student team thesis was conducted across six convenience sampled textiles and apparels companies in Karachi, Pakistan, as exploratory research. Interviews of purposively sampled personnel from these companies were assessed on their awareness on sustainability and the initiatives taken to develop infrastructures in alignment with green value chain standards and sustainable product. The instrument used is an unstructured questionnaire developed by the student researchers from adopted aspects of the Global Reporting Initiative standards. The use of thematic analysis and Greening Goliaths vs Emerging Davids Sustainability Matrix was further essential in this study's potential in proposing green marketing strategy (GMS) to the Ministry of Textile Industry, and the All Pakistan Textile Mills Association. The study brought to light the detriments to market penetration of sustainable textiles and apparels in Pakistan, namely the economy, and consumer behavior. Conclusively, the student researchers found that the textiles industry in Pakistan was well developed along global sustainable goals but demand for sustainable apparel stemmed from developed nations owing to their consumer's awareness on the implications of inorganic derived apparels on the environment
\end{abstract}

\section{OPEN ACCESS}

(C) 2021 The authors, under a Creative Commons AttributionNonCommercial 4.0

Corresponding author's email address: maryamhina83@gmail.com

Recommended citation: Zikria, H. M. B., Irfan, M. \& Umar, F. (2020). Assessment of Sustainable Development in Apparel Value Chains. Sustainable Business and Society in Emerging Economies, 2 (2), $21-40$

\section{Introduction}

In 2015, the United Nations developed an agenda of 17 Sustainable Development Goals that outlined proactive initiatives to achieve them before the year 2030. The $12^{\text {th }}$ goal is regarding sustainable production and consumption patterns. The report does not mention any county by name, rather regions are mentioned, of which South Asia is given much statistical prominence as the region most hit by non- 
sustained development induced pollution in every form imaginable (The Sustainable Development Report, 2019). There is the underlying assumption that Pakistan could very well be justified having a part in these statistics as is apparent by recent news reports (Dawn, 2019) (Asia Times Staff, 2019) that puts the nation at heights of non-sustainable business trends with vast repercussions for the social and economic ecosystems.

In the Pakistan National Actional Plan Report of 2017 for Goal 12 (Sustainable Consumption and Production), there were only two mentions of 'green supply chain' to be considered for adoption in the industry sector, of which the sub goals stressed for companies and industries to induct sustainable reporting, (12.6) curbing their effect on the environment (12.7), and educating on sustained consumer behavior towards commodities and resources (12.8). (Pakistan National Action Plan on SDG 12, 2017). It is quite alarming that hardly any change is being observed on a significant scale owing to other sociopolitical detriments plaguing the nation and standing in way of progress to better goals.

A very prominent part of human production and consumption is the need for clothing, of which there are offshoots of textiles, garments, and luxury apparel. (The Sustainable Development Report, 2019) with the advent of man-made fiber and easily available faux materials, produced on a massive scale thanks to industrialization, fashion has gained a faster pace and value for the mass consumer. Textiles, apparel, clothing, and garments, have become slave to the dynamic and highly competitive fashion industry, and the innovative consumer is targeted by strategic marketing campaigns to shift to newer apparel designs in touch with current fashion standards. The fashion industry itself is a very elaborate value chain with consequences weighing more than the merits. (Yadlapalli, 2015)

Narrowed down to the scope of our research and with respect to the UN Sustainable Production and Consumption goals, in essence, we do find there is a certain degree of disregard for social and environmental responsibility demonstrated by the sourcing, manufacturing, and marketing procedures of prominent apparel businesses categorized to the textiles industry sector. Labor is abused, textile chemical waste released into the open sea, cloth dumped in landfills or discarded near habitable areas. And all in the name of capitalizing on fast fashion. Our consumer trends for apparel are so fast paced that the demand generated does not allow for sustained or responsible generation of supply in respect to the very ecosystem preservation we strive for. (PakistanToday, 2019)

The issue lies with the lack of absolute knowledge where apparel businesses stand with regards to sustainable development initiatives as contributing members to achieving SDG ${ }^{1}$. While it is true that some brand apparels are taking the green initiative to some degree in Pakistan (LAKDAWALA, 2019), there is still the fact that small and medium business enterprises sectors do not report on their sustainable practices or initiatives owing to their inability to comprehend what the concept of sustained practices are (Zeeshan Mahmood, 2017). It has been cited that when such social responsibilities are implemented for upholding pillars of sustainability in an apparel supply chain, the manufacturing chain links used devious and defensive methods to cover up their non-sustained practices (Chang, 2015).

In this regard, this study seeks to explore the current trends and developments in sustainability in textiles which would act as supplementary material for future students in business, textiles engineering.

\section{Literature Review}

\subsection{Subsumes of Sustainability in Business}

Sustainability is the philosophy to conserve usage of current resources so as not to compromise these resources for the use of the future generations (Redclift, 2006). It is a way of life, a belief to be inducted for the sake of responsibility in living. In terms of businesses, sustainability stresses on extensive foresight and accountability in the design and development of organizational goals that do not

${ }^{1}$ Sustainable Development Goals 
compromise on environmental and societal integrity in greed for monetary gains. (KENTON., 2019) The business model in line with current sustained standards is bound to balance morals with money, which further translate into the triple bottom line model with the dimensions: people, planet, and profit. Developed by John Elkington, this concept allows companies to strive for sustainability goals through evaluation of their performance in the environment, society and their financial activities. Thought having no units of measurement, these dimensions, or pillars are quantized by currency impact or indexes, but often incidents like ecosystem damage and pollution as a result of business activities cannot be gauged for their severity and hence remain biased. (Hall., 2011).

Often sustained aim efforts have failed to allow profit capitalization owing to the fact that sustainable business models are largely situational and require specific alterations to shape a more economic, societal, and environmentally friendly approach in the long run (DAVID KIRON, 2013). This essentially means the environmental and societal contributions diminish a business's longevity because such commitments mean compromises in profiteering. Moreover, the increasingly high consumption of products cites more lapses in sustainable business initiatives and policy adoption.

\subsection{Sustainable Development and Responsibility}

In recent years 'Sustainable Development' has emerged as a catchphrase to encompass profit and nonprofit activities that are structured to conserve and protect the integrity of the planet, especially in the light of global and environmental issues. The concept comes from a simple definition of fundamental objectives meeting current needs and sustainable requirements. (Lele, 1991). In this regard, science and technology are necessary components in promoting sustainable development. (cash, et al., 2003). Advocating a step toward sustained progress is a critical undertaking that would require extraordinary commitments from political pioneers, business people, and civil society actors working together over scales (Clark, 2016).

And speaking of development along conservative lines, the concept of CSR emerges as a further related term for a more strategic business approach to sustaining stake holder interests (profits) in an ethical manner with minimal harm to the environment and initiatives to add more value to the society (Marina Prieto-Carrón, 2006). Sustainability and Corporate Social responsibility do go hand in hand with regards to their concern for areas that business activities might affect negatively, and they seek to neutralize and hamper these effects for business longevity, public relations, and philanthropy. However, corporate social responsibility is more dedicated to a business's reputation, while sustainable practices extend towards a lifestyle as well.

\subsection{GSC, GMS, and Resource Constraint Production}

These terms are highly inter related by way of corporate and strategic environmentalism. Green supply chain management incorporates the triple bottom line (3BL) model to keep their business sustainable. The green market strategy is another emergent approach taken by organizations to induct organizational process that involves aspects of the $7 \mathrm{Ps}^{2}$ of marketing, redesigned to develop products that incorporate the least damage to the 3BL model for sustainability. Largely the interests have been to minimize the impact of the human carbon footprint, conserve resources, recycle, educate the poor, and make supply 'chains greener'. (Arun Sharma, 2012) (Hall., 2011) (Marina Prieto-Carrón, 2006)

Resource constraint production is essentially a capacity and production planning term where by demand fulfillment is dependent to the availability of inventoried raw supply (Puigjaner., 2018). Not strictly a sustainability concept since it is from a demand and supply perspective, but it does focus on the control of sourcing that affects production, which is an identifier to the main concept of sustained practice.

\subsection{Detriments and Motivators}

In concise words, for the apparel industry the biggest challenge to sustainability development is high

\footnotetext{
${ }^{2}$ The 7Ps are factors considered in designing and delivering product or service in respect with demand and supply to maximize customers preference.
} 
consumerism (fast fashion) and globalization of trade (Magnus Boström, 2016). This hints at the complexity of apparel supply chains since factors like government regulations, trade unions, policies, sourcing options, budget constraints, and resource allocation can hinder the rate at which sustainable development can occur in a nation's domestic markets that can act detrimentally to such development.

Another detriment is the consumer's perception of what it means to buy a sustainable apparel product, the study focused on the consumption behavior of customers who were made aware of their consumption tendencies and then evaluated for their renewed perception. The research concluded that making consumers aware of the environmental impacts of their purchase decisions made them feel responsible towards changing their consumption selections. (Nazan Okur, 2019)

\subsection{Sustainable Fashion in the Apparels Industry}

With respect to clothing, the recent trend has been fashion eco-awareness, ironically parallel to the growing demerits of fast fashion. Apparel businesses have been made to focus much on the ethical transparency of their operational functions, and to remodel their value chains to incorporate sustainability procedures beyond just the fabric esthetics. The true issue with sustainable apparels is their complex value chains, short product life cycle driven even shorter by the seasonal apparel range releases, which does not make the industry an easily sustainable one. Hence the conclusion is that the mix of apparel quality and sustainability is difficult to achieve simultaneously. (Yadlapalli, 2015)

The fashion industry is regarded the main trend setter because this industry encompasses designers, influencers, and brands, required to set the textiles and apparel industry in motion from the demand/supply aspects. Research suggests that sustainable efforts have been lacking in fashion apparel primarily because the trend setters and designers are either not aware or not willing to bring about change in their base materials, and the only efforts being made are mere marketing stunts in niche markets that are more of a luxury than economically beneficial (Hahn, 2014).

Apart from the fashion considerations, labor rights also form a part of sustainable apparels approach. The United Nations actually has a standard certification for ideal labor work environment (ISO 26000: Guide on Social Responsibility, 2018), but in south Asian countries the reality is labor exploitation by global apparel brands. (Hahn, 2014). In fact, substantial literature focuses on the social harms of apparel production that present a sustainability challenge. (Magnus Boström, 2016)

The aim for sustainable development is environmental integrity, business prosperity, and healthy social framework (Crofton, 2000) However, the apparel business is a significant supporter of environmental issues from clothing creation to textile landfills, with only profits in sight. (Gam, Cao, Farr, \& Heine, 2009). Incorporating sustainability into the apparel supply chain is becoming a key priority for many textile and apparel companies. Sustainability issues in the textile and apparel industry have gotten incredible consideration but the efforts have yet to reach fruition. With geographically long and complex worldwide networks, just as the double weight for cost and lead time, implementing sustainability in textile and apparel supply chains is challenging. (Shen, Li, Dong, \& Perry, 2017)

\subsection{Sustainable Apparel Concept in Pakistan}

Pakistan, despite being among the top 5 nations in raw cotton production and a robust textile industry, lacks in sustainable practices, even with governing policy outlining the need for sustained green approach to the apparel value chain. (Textile Policy (2014-19), 2015). Interestingly, a report on Pakistan's position in the global apparel chain cites the progress deceptive because the information is only limited to a handful of apparel business with not much of a diversified portfolio in products (Stacey Frederick, 2019). The sustainability concept is present in Pakistani apparel businesses judging by the sufficient literature found that focused on textiles and clothing sustainable challenges along the CSR, GSC, and sustainability reporting perspective, but the conclusions encountered were regarding a lack of reporting on sustained practice or green supply chains, as well as misaligned CSR priorities, and 
dishonest reporting. (Usama Awan, 2019) (Zeeshan Mahmood, 2017).

However, there are apparel brands attempting to propagate sustainability as a lifestyle through small consumer delight tactics. One brand offers custom dress designing from left over fabric parts, another is imbuing their paper bags with seeds, and one apparel business has been marketing their less water approach to preparing clothes. Unfortunately, these tactics are not documented in grounded research and have been available through media channels, which is another indicator of the infantile and premium stage of sustainable practices that does not offer economy as yet. (LAKDAWALA, 2019) (Saeed, 2019). There is evident research that outlines the socio-economic benefits by integrating CSR practice through environmental management systems in some manufacturing companies in Pakistan (M. Ikram, 2019), and another research outlines positives of green supply chain integration in textiles and clothing in terms of trade and environmental performances (Muhammad Naveed Ikram, 2019), these researches are largely quantitative but show promise.

In stark contrast, Sri Lanka and Bangladesh are progressing by bounds in sustained green practices in their apparel industries owing to the base focus on responsible fashion, employee empowerment, and job motivation factors, waste management in fabrics, as well as proactive approaches to business expansion as their industries enter the global export platform. (S. Gunapalan, 2019) (Asif, 2017).

\section{Materials and Methods \\ 3.1 Instruments}

An unstructured questionnaire comprising of 16 articles was developed using the 2016 Global Reporting Indicators issued by the Global Sustainability Standards Board. These standards are available as universal best practices guide sets that prepare an organization to report their sustainable activities across the 3PL model (profit, people, planet). The researchers had deemed philanthropy and economical activities exempt from their scope unless uncovered in the contextual analysis, hence the topic-specific Environmental guide (GRI 300) and Social (GRI 400) was used along with General Disclosures (GRI 102) and Management Approach (GRI 103) to develop an unstructured questionnaire ${ }^{3}$. These questions will also be acting as guide themes in the contextual analysis. (Global Sustainability Standards Board, 2019).

\subsection{Sampling}

Convenience sampling was used for selection of companies that dealt with both textile and apparel manufacture, dealt with local market trade and exports, and were willing to allow the student researchers on premises for conducting voice recorded interviews. Six companies responded on the ethical condition that they not be named directly. From these companies, a total of 11 respondents came forth from judgmentally sampled designations of operations, procurement, product development and CSR, to give their perspective on sustainability, its development in their company, their contribution to the integrity of the social and economic environment, and future endeavors to actualize the Sustainability Goals. In this duration, the researchers realized the personnel most aware on sustainable practices are product developers.

\subsection{Tools}

The audio recorded interviews lasted from 30 minutes to over an hour. They were translated from Urdu to English by the researchers and transcribed for thematic contextual analysis which assists in developing patterns and themes across qualitative data. Respondents were given the listed questions and were free to respond in what manner they wished. The Braun and Clark Six Phase Thematic Analysis Technique was used (Braun, 2006). This type of analysis requires the researcher to be intimately involved with the raw data and not to be subject to perceived bias, hence the addition of an external auditor to remove this bias (Creswell, 2014), which was maintained by supervision. The researchers felt

\footnotetext{
${ }^{3}$ Questionnaire is attached at Appendix C.
} 
confident in using this method because of their grasp on the linguistic intricacies in translation and interpretation.

Another tool used was the Greening Goliaths vs Emerging Davids Positioning Matrix ${ }^{4}$, adopted from a prior research, that used brand value against sustainable content mentions in their corporate reporting as plot coordinates (Yadlapalli, 2015). Since some of companies sampled in the current study did not have corporate reporting available to outsiders while others had no such reporting, hence, based on the responses to the questionnaire developed from the GRI standards, the researchers assigned relative scores as Sustainability Assessment Score ${ }^{5}$ to each company. This score was plotted against sampled companies ages to categorize them into either Ecopreneurs, Davids, Goliaths, and Sustainable Entrepreneurs on the position matrix. The purpose was an attempt to visualize with limited data, where these companies stand in terms of the sustainable developments towards their product development, waste disposal, management, sourcing, product information, effects on local communities, social responsibilities, and environmental concerns, with the passage of time.

\section{Results}

\subsection{Thematic Content Analysis}

Given below is the development of an extensive thematic map centering on assessed sustainable development in the textiles industry in Pakistan, exclusively derived from the content analysis.

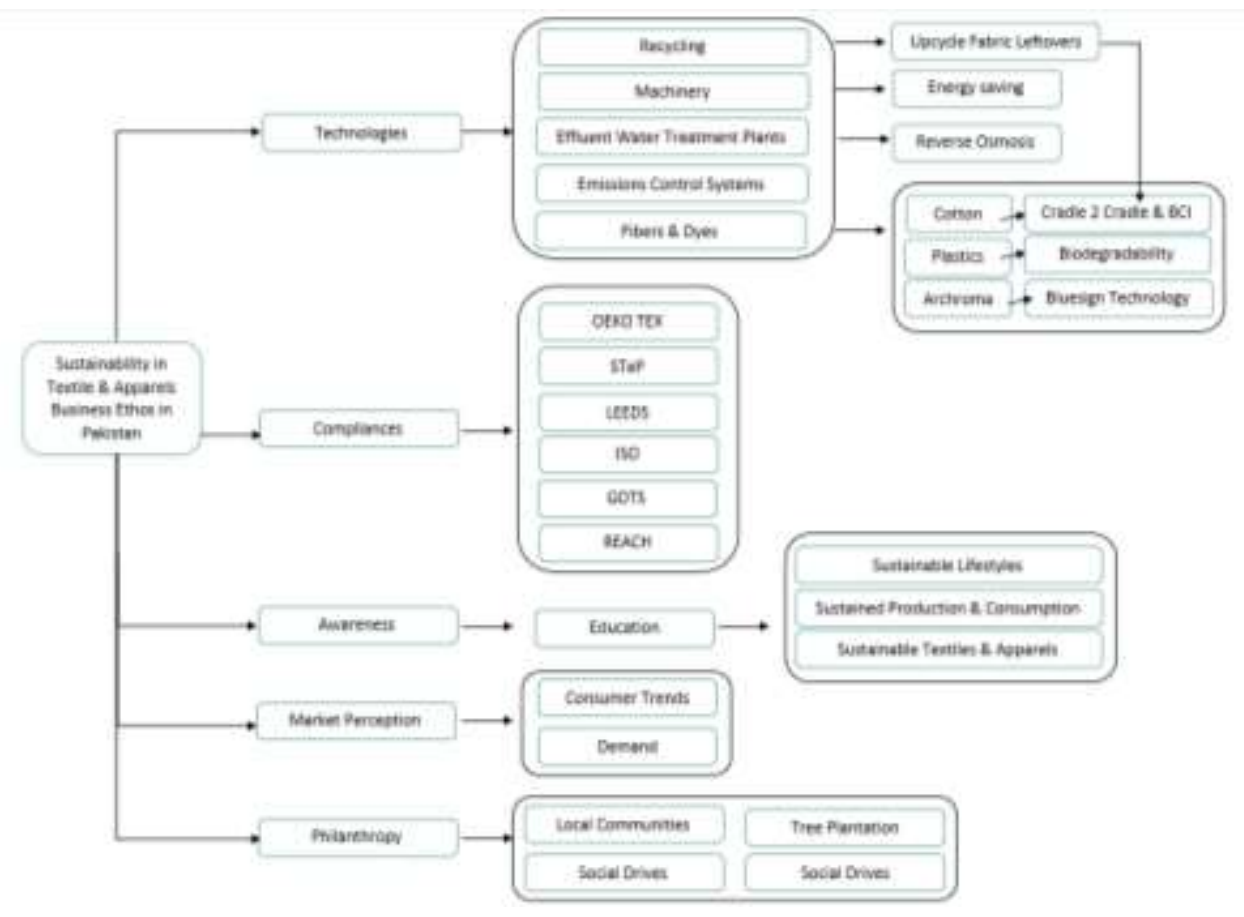

\subsubsection{Derived Themes}

Figure 1. Thematic map laid out as a divergence tree from condensed topics to specifics.

\section{Technology}

It was apparent from the analysis that respondents believed that organic cotton requires much more care than conventional petroleum-based fibers, and is globally a niche product, hence the costs are higher. They also stressed that only economies of scale can balance the high technological costs of sustainable fabric with market penetration, and that is the view often reflected in organic agriculture (Scialabba, 2013). Company $\mathrm{C}$ had established post-consumer waste treatment of denim products, a fact that was

\footnotetext{
${ }^{4}$ Sustainability Matrix given at Appendix A, Figure 4.

${ }^{5}$ Assessment Score is given in Appendix B, Table 2.
} 
mentioned by respondent of other companies. Interest in recycling philosophy like 'Cradle to Cradle' (Cradle to Cradle Products Innovation Institute, 2019), sourcing from organic dye solutions like bluesign solutions and Archroma, and 'better cotton initiative' for superior crop quality, along with a shift to investing in solar energy were explicitly stated. Having technical know-how of air jet looms, effluent treatment plants, and 'zero water' denim dyeing was revered, while cotton sourcing criteria, textile waste disposal, and labor safety on the factory floor were deflected with generic responses of functional harmful gas emission control systems and labor welfare programs.

On a conclusive note, it was observed that across the sampled companies, technology and business process engineering was only a successful precursor to sustainable efforts if the human capital involved was as efficient in operating the said technologies and the required equipment.

\section{Awareness}

Respondents across a wide designation range were aware of the meaning of the sustainability itself, but few could vocalize the concept of conserved usage of resources in the present to allow for prolonged usage for future generations to come. Respondents from Company D understood sustainability as in its financial concept, to help maintain the business as long as possible into maturity while acquiring sufficient market share.

Respondents from Companies $\mathrm{C}, \mathrm{E}$, and $\mathrm{F}$ were adamant that sustainability is not just a best practice to be adopted into a business, it requires a complete change in the mindset of the inhabitants of Pakistan, and stressed on the need for basic education in responsible consumption and waste management. The opinion was unanimous that fashion is a fast industry and will always need more consumption to meet the demands of the consumers.

\section{Compliances}

Having adequate knowledge of the certifications in textiles and apparels manufacture was a matter of pride for the respondents. The credit for achieving certifications like OekoTex and STeP was attributed to the demand from developed nations since global competition was believed to be the real motivator in staying up to date on quality and service standards.

Regarding further discussion on the nature of these compliances, it was established that certifications are designed to reengineer business practices beyond the silo mentality of profiteering and financial stability. This included elevation of employee actualization that sustainability is not just a word but rather a practice that takes on a holistic approach towards every stage in the textiles weaving and apparels manufacture. Investors conducted audits on these companies, especially on the quality of life of the labor and their welfare, right down to their sanitation. Moreover, foreign customers got a sense of involvement and responsibility from their audits and this helped attain further certifications since it allowed exposure to customer requirements and technological acquisitions in an expanding market.

\section{Market Perception}

According to the analysis, the general attitude maintained in the textile market in Pakistan is to source cheap material to meet consumer demand of affordable textile and apparels products. Fast fashion demands make sustainable production of textiles and apparels even more difficult as Pakistan is a lowincome per capita country. Additionally, recyclable, recycled, and upcycled textiles, fabrics, or apparels products are not usually affordable by low-income families, making the market for sustainable apparels quite non-lucrative for textile companies striving for international quality product. One respondent of Company C stated, "the local brands don't want to work with us to be honest. Like if there is a big brand in Pakistan that is willing to work with us then its Oxford, if they want to, because our prices are slightly higher.".

Another respondent Company D said that regarding local markets, the issue is affordability of quality sustainable product. The domestic consumers demand more variations in apparels but compromise on quality because of short term use. Quality products are subject to dollar fluctuations in the exports 
market with makes them lucrative unlike the Pakistani market where the consumer is perceived to think that buying long lasting organic cotton products is expensive and will be out of fashion soon, here the respondent concluded with, "what they (consumers) compare is the affordability not quality.....In short people don't seek quality”.

It was recurrent in the contextual analysis that local market perception of sustainable apparels is in direct contrast to the fast fashion market trends, the youth are not educated enough to comprehend responsible consumption, nor is the human capital of Pakistan sufficient to generate an economy where a market for sustainable apparels could thrive and boost responsible consumption. The general notion however existed in these companies that the denim industry is the most viable for setting an example in sustainability in manufacturing, and that businesses are making sustainable denim production a marketing tactic because denim has matured as a product globally and this is the only direction left for them.

\section{Philanthropy}

Corporate social responsibility was a much-emphasized factor when justifying sustainable development. Labor satisfaction and enhancing of quality of life was regarded crucial to the textiles business, yet on the ground it was observed that only one company made efforts to not only publish a CSR report for foreign stake holders, but they also actively educated their labor in basic arithmetic, English, and Urdu (Company F). Out of the entire sample, Company E and F exhibited a practical concern for merging sustainable practices into philanthropy that leads to consumer education. Both companies expressed the importance of the human labor that needs to transcend humanitarian levels and think for others rather than selves.

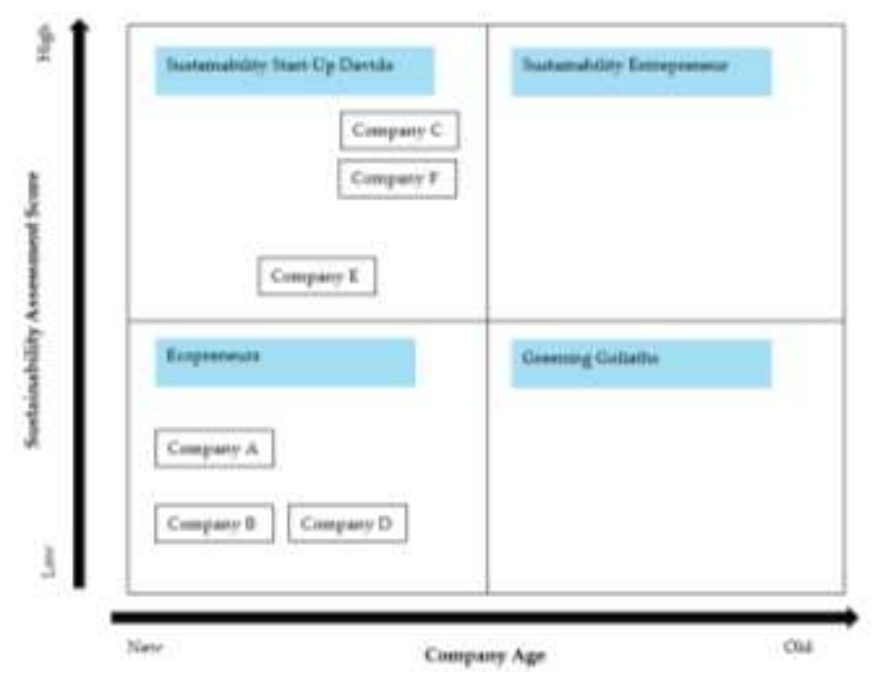

\subsection{Sustainability Positioning Matrix}

Figure 2. Textile companies sampled categorized as per their sustainable scores and attributes ${ }^{6}$ on the matrix.

Company A \& B are an apparel manufacture business that are related but only distinguished by the luxurious offering in Company B. Their main focus is on market penetration in global markets and financial stability. Their competitor is Company D that was established primarily as an apparel manufacture business for men's clothing which gradually expanded to accommodate women's fashion. They deal with stitching, printing, and designing from outsourced fabric that is incumbent of fast fashion materials. They deal with a 'fusion' of eastern and western wear to secure market share globally. Their

\footnotetext{
${ }^{6}$ Attributes given in Appendix B, Table A.
} 
stated aim was also to maintain a financial sustainability first and philanthropy was not mentioned. Their only complimentary act on the merchandising end was the offering of fabric biodegradable bags. The same marketing tactic was followed by Company E which is regarded as Pakistan's largest dyed yarn producer. The stated using biodegradable plastic and paper bags to customers on purchases. They also expressed concern towards educating locals on sustainable practices as a lifestyle as well as collaborating with textile institutes to produce more sustained production methods that complement the UN Sustainable Development Goals. Their initiatives as a sustainability startup also includes MOUs with textile educational institutions, however contrary to their claim of being a LEEDs Certified unit, there was no proof found by the researchers during the background check. (Certification Standards Approved, 2019) (Green Building Information Gateway, 2019)

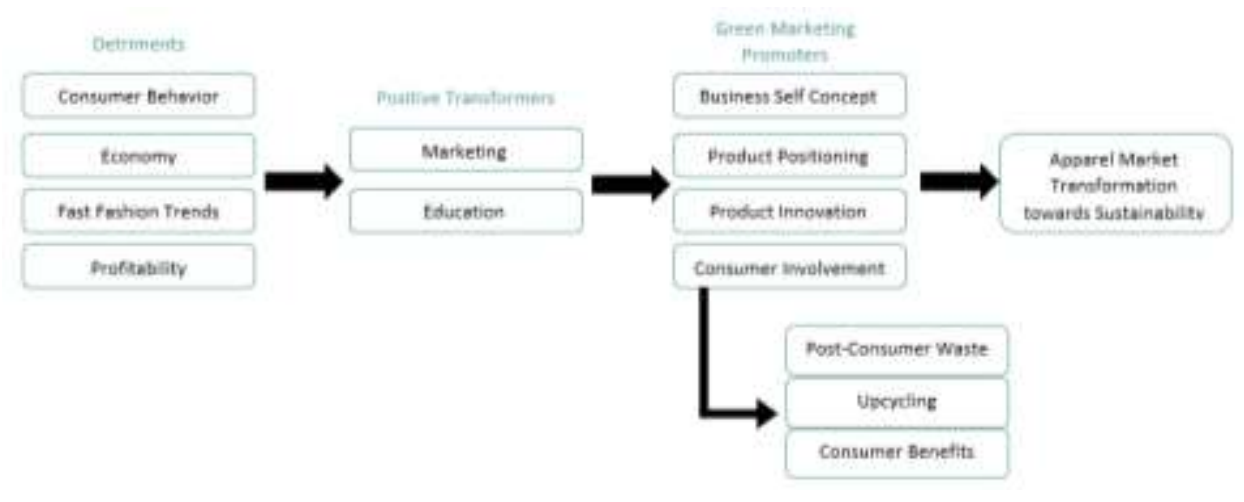

Figure 3. Emergent themes arranged by virtue of their causality, leading to market transformation.

The most significant cases in terms of sustainable development were Companies $\mathrm{C} \& \mathrm{~F}$. Company $\mathrm{C}$ began as a denim apparels manufacturer that backward integrated into yarn, spinning, processing, and product innovation of denim. They have a global presence with sustainably designed manufacturing unit in Bangladesh, and a second Platinum LEEDS certified facility deployment off the N5 Highway in Karachi, and extensive supplier market share across European, North American, and Latin American fashion apparel brands. They also have established a fully functioning recycling facility that deals with Post-Consumer Waste (PCW) to regenerate fibers. .Similarly, Company F boasted extensive developments to their supply chains with in-house designed inventory stocks systems, lean management, just in time layouts, minimal fabric waste, and proactive approach to sustained business strategies. This company dealt purely in exports of apparel, garments, bed linens, uniforms, and workwear. They focused on improving the quality of life of the labor as a prerequisite to higher production efficiency. Point to be noted is that Company $\mathrm{F}$ was a result of a diversified business strategy into fabrics production.

Conclusively, the matrix shows the companies $\mathrm{C} \& \mathrm{~F}$ as sustainable startups because of their integration of sustainable practices in management, production, and apparels. Company $\mathrm{E}$ is also a relatively young sustainability startup that is adapting to their new environmental management systems. Companies A, B, \& D are focused more on the apparels designing, stitching, and merchandising end which means they have yet to acquire sufficient market share and adopt significant sustainability practice.

\section{Discussion Recommendation}

Based on the findings of the thematic analysis and the sustainability matrix, the following chart was developed to organize detrimental factors that can be transformed to enable Green Marketing as a suitable path to instilling sustainability in Pakistani textiles. 


\subsection{Detriments}

These factors are derived as hinderances as discussed by the 11 respondents when they all explained the lack of profitability in the organic apparels business, high quality fabrics, and sustainable fabrics, in the domestic market. After consistent data familiarization and review in the findings stage the following factors arose that were a direct influence on the state of sustainability in the apparels industry in Pakistan.

\subsubsection{Consumer Behavior}

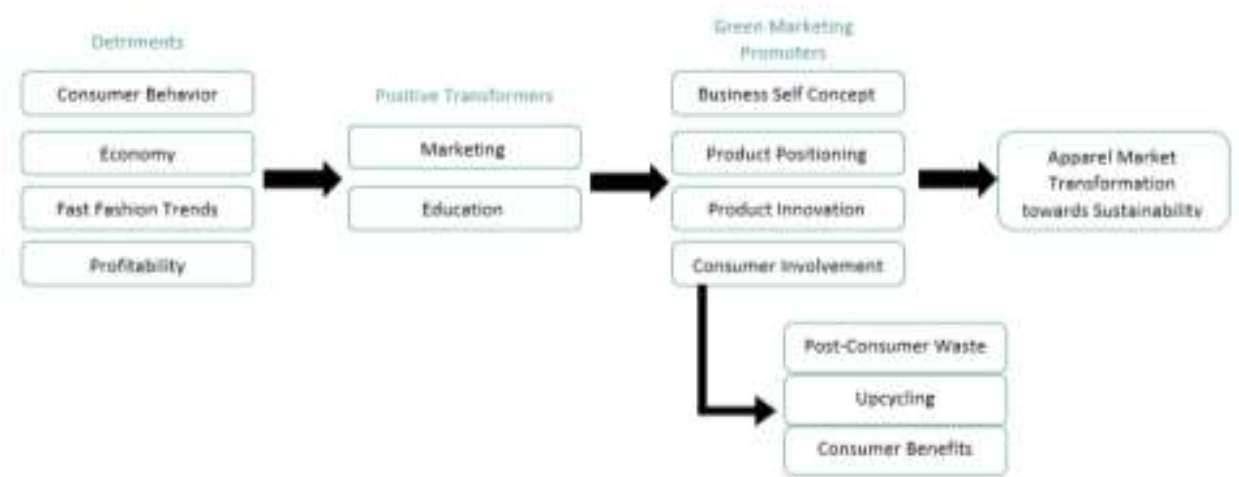

As was uncovered in the theme of awareness, it was revealed that the textiles business is a pull-based industry with many competitors in the exports business. Foreign buyers initiated purchases from textiles and apparels companies in Pakistan on basis of their own end consumers being a target segment that understood the implications of conservation, sustainability, and resource constraints in their global production and consumption of commodities. These foreign consumers knew exactly what kind of textile material they wanted. Furthermore, these consumers have set up examples in post-consumer waste recycling. Since Pakistan has been mentioned in the analysis as a major organic cotton grower, it means opportunities for foreign buyers who would like to invest in a better product. Hence textiles units in Pakistan have been upgrading their infrastructure on par with international standards to compete in the export market.

In stark contrast, there are the consumers in Pakistan's domestic market which focus more on affordability rather than the impact of non-sustained petroleum imbued man-made fibers. There are numerous sales occurring all year round from clothing outlets whose products may cost cheap but hardly last because the consumer is influence by the domestic culture of fast fashion seasonal sales. Since these apparels are cheap to make without economies of scale, it directly means that these fabrics are made of low grade non-organic cotton mix that will not biodegrade into the environment without harming it. This is perhaps a major detriment to the transformation of the apparels industry to a sustainable one.

\subsubsection{Economy}

Since a lot of Pakistani textiles companies are exports based and source to foreign apparels and textiles brands, it means that the more premium product is exported to these high-income nations. Across the sample it was revealed that such buyers also belonged to the high capita economies in Europe, North, Central, and Latin America. These developed countries were in a more aware state of mind with regards to responsible use of resources in the face of non-renewable resource depletion.

In stark contrast, low capita economies such as Pakistan, find it difficult to afford quality apparels, hence this contributes to the dominant cheap demand for clothing and textiles. With the local currency devalued ${ }^{7}$, the exchange rate only profits the exports industry in gross national product. The local economy is weak enough to attract foreign interest owing to Pakistan's organic cotton, and this way many textile and apparels companies have expanded their operations and achieved international

${ }^{7}$ One Dollar $=154.95$ Pakistani Rupee $\left(\right.$ as of $31^{\text {st }}$ December 2019) 
recognition for their quality product, while the domestic buyers either prefer to source cheaper cloth from China and remain a majority of contributors to textile and apparels pollution. The issue remains the same, locals are not wealthy enough to afford organic sustainable apparels.

\subsubsection{Fast Fashion Trends}

Fast fashion is a major demerit to the efforts and ideology of sustainable production and consumption. In the thematic analysis, it was discovered that the sampled companies had dealings with Zara Basic, which is Inditex's fastest fashion supply chain in the world, but another surprising fact was that this fast fashion was also rendered sustainable, because not only Zara, but Sainsbury, Walmart, Lefties, Izot, and H\&M, were sourcing custom pro-organic apparels and textiles from three of the companies sampled. These fast fashion items were designed obviously to mimic top designs in the global fashion industry, but they were designed also to biodegrade with minimal effect to the environment.

In the domestic market, fast fashion is a problem because the base materials for the apparels demanded by consumers are cheaply derived and do not biodegrade for a long while. So, the local consumers may be purchasing from sales upon sales of short life cycle materials but eventually these textiles will end up in a landfill and would not decompose for a long time, further adding to the polluted state of Pakistan.

\subsubsection{Profitability}

Perhaps the most mentioned issue in the content study was the lack of profit in the domestic market with regards to environmentally friendly and sustainable sourced product. Since sustainable apparels involve a lot of considerations in their sourcing, processing, manufacturing, and reverse supply chain which are structured on international standards, hence the costs added are high. Naturally one would assume that sustainable apparel products ought to be cheaper in quality because no fertilizers or pesticides or harmful dyes have been used, nor has there been any cross contamination in the fabric weave mix, but the truth that emerged was by far different. It was argued that since none of the sustainable processes involved misuse of labor hence that may add to the charm of the finished product. The reality is that in keeping with international organic and sustainable standards, organic apparels are not developed on economies of scale as yet to cater to a global audience. Global consumers are becoming aware of the sustainability movement and initiatives have been developed in far developed countries to ingrain conservation in their product and services offering.

In this domestic market, the economy is already weak and the consumers are not responsibly aware of the consequences of their low-quality affordable fast fashion demands. The usual marketing tactic is cost reduction and product differentiation to penetrate the markets but since organic apparels are emerging as a premium product, one argues that it is more profitable to enter the domestically produced sustainable product into the export market for higher revenues since there is more demand for organics in the international markets than the domestic markets.

\subsection{Positive Transformers}

These are the factors that emerged in the analysis to act as positive mediums to shift the domestic market perception from cheap fast fashion, to the more sustainable and premium end. As consumers, our exposure begins with schooling and media, and these are the best mediums with which to influence future consumers towards ingraining sustainability into their lifestyles. This will open up an entire new pull-demand market for not just apparels but for other organic products as well. Rather than change clothes for every season and massively contribute to the environmentally harmful deposit of rotting plastics derived fabrics, opt for fabrics that will last as long but will not harm the user's skin or the environment. Additionally, it would add to the consumer's self-perception of having positively contributed to the environment.

\subsubsection{Marketing}

In the duration of the study, it became apparent that intensive marketing tactics have to be employed in the fashion, clothing, apparels and textiles industry in Pakistan. Consumer behavior should be reengineered on a massive scale to make sustainable products more attractive to consumers regardless 
the cost. As covered in the literature, there are small scale enterprises that use consumer delight tactics such as fabric envelopes, seed infused bags, upcycled apparels, and biodegradable bags. These are not sufficient for bringing about a change in the market perception of sustainable apparels. These activities are just complimentary premium acts of an ecopreneur scale. What is required is informative marketing to raise awareness among the general public to shift towards fabrics that have been certified organic mix apparels. This would develop a domestic market for sustainable apparels and perhaps transform the consumer perception.

\subsubsection{Education}

This theme emerged as a subsume of awareness in the main thematic analysis, but its implications are beneficial if used in the textiles engineering and fashion design industry. The reason this theme has been repeated again is because there was an interesting discussion put forward by two respondents of Company E that was their company's initiative towards involving students to come up with innovative research projects to develop sustainable textiles at higher production and low costs to better cater to the domestic market. Additionally, they also seek to transform the mentality of the domestic consumers to revert to sustainable lifestyle practices by inclusion of coursework with the UN Sustainability Initiatives in mind.

The respondent themselves was the person that took up the initiative to sign up MOUs with textiles designing institutes and they invite students to use their facilities to engineer textiles and machinery. This respondent believed that since awareness was not the sole solution to creating a market for sustainable apparels, hence efforts must be made to educate the younger literate generation. Another respondent of Company $\mathrm{C}$ was also of the belief that globally sustainability will become a fashion itself with stake holders willing to invest heavily for stable returns in the future. However, the fate of the Pakistani apparels market will only improve if the acceptance towards organic apparels begins in the education of the public itself.

\subsection{Green Marketing Promoters}

These are the obscure themes that were mentioned in minority across the sample but have been considered for their implicit green marketing strategy markers. These are the themes that provide legitimacy to developing a response for the second research question. The context in which the researchers are attempting to use the GMS is to develop proactive solutions for a market transformation towards sustainable apparels in the domestic market.

\subsubsection{Business Self Concept}

This theme emerged from the discussions that corporations and enterprises use their self-concepts on sustainable offerings, green product, organizational efficiency, and international certifications to boost their market presence. This was argued by the sampled companies that had exports-based business at an 80-29 ratio, where the 20 marked their dealings in the domestic market, which was yet argued to be an imperfect valuation.

But potential lies in these export-based companies to start sourcing their products to local apparel outlets and then build an immersive customer management system. The sampled companies have established their reputations globally, and a few of them are considering expanding into the domestic market, one company has launched a series of studios and is making progress with creating affiliations based on their self-concept of quality with environmentally friendly apparels.

\subsubsection{Product Positioning}

This factor emerged multiple times as the problem of too many sales seasons each year which set competitors in a never-ending cycle of the sales trend. Anything in a sale is positioned to capture the masses in a tactic to lighten the inventory, as a respondent of Company F observed on the objective of lean supply chains. Organic products are already perceived as high end, couture brands with further 
value addition brought on by petroleum-based fabric additives to add the shimmer and texture, where as it was discovered during the analysis that one company offering premium couture apparel was actually environmentally compliant but non-sustainable apparel with plastic or cheap metal embellishments. Hence there is a possibility that apparel products may not be necessarily organic even if the company manufacturing them claims to be environmentally compliant.

Therefore, in light of this information, apparels products should be positioned to reflect the sustainable efforts that were put into manufacturing them and how they affect the environment. This same company uses their business ethos of charity and humanitarianism to boost their sales which is deceptive yet again because their product is not sustainably positioned. Comparatively, Companies C, E and F were completely transparent about their product positioning and how it impacts their consumer's world.

\subsubsection{Product Innovation}

This green marketing promoter was apparent in some discussion, one respondent claimed they were trying for innovating fabrics that had sufficient organic content but with less carbon footprint on the local environment. In the analysis there were various forms of fabrics that played a certain role in the final finished apparel item. This tactic was discussed to be evident in foreign nations as the buyers often specified the composition of the fabric or stitched apparel they required. However, with regards to the domestic market it was discussed that often fabric and apparels were just imported from China without even asking much questions as to the traceability of the product. Product innovation in Pakistan in terms of apparels is much promoted by the fashion industry, but fabric innovation needs more focus to be made of a mix of materials that are cheap, breathable, quality, and biodegradable with minimal carbon impact.

\subsubsection{Consumer Involvement}

Perhaps the most important emergent theme to occur in the sample, a respondent of Company E, reflected upon a patency launched in Spain by the company of SEAQUAL, in which they have initiated a movement to reclaim plastics from the seas. (SEAQUAL, 2019). These plastics are then used in recycling to make polyester apparels that can be recyclable again. It seeks to bring together people in large communities at coast line countries to contribute to cleaning up the oceans from plastics pollution.

Similarly, this was the consumer involvement tactic adopted by fast fashion outlets like H\&M and Zara, where consumers would return their used apparels and receive a discount for next purchase. These postconsumer apparels are being shredded down at a fully functional facility at Company $\mathrm{C}$ into regenerated fibers that are again woven into textiles and stitched into garments. These tactics are green examples set abroad that have potential for implementation in Pakistan as well. If the consumer is made to feel like they are more than just a revenue source, and more of a sustainability advocate, then this may add further to the consumer satisfaction and retention.

Table 1. Recommended Green Marketing Promoters using the 7P framework.

\begin{tabular}{|c|c|}
\hline GMS Concepts & Tactic Deployed \\
\hline Product Concept & $\begin{array}{l}\text { 1. Initiate Cradle-2-Cradle into not only textiles but in the apparels as well. } \\
\text { 2. Develop environmentally friendly design into apparel composition. } \\
\text { 3. Involve fashion designers in sustainable product development to innovate designs } \\
\text { into organic materials. }\end{array}$ \\
\hline Price Setting & $\begin{array}{l}\text { 1. Provide the apparel product at competitive prices. } \\
\text { 2. Adjust costs of production and economies of scale for future reduced prices to } \\
\text { avail lower classes to add to the market share. }\end{array}$ \\
\hline Positioning & $\begin{array}{l}\text { 1. Develop a hybrid of lean operations and sustainable supply chains to substantiate } \\
\text { the claim of a green product. } \\
\text { 2. Textile companies should forward integrate and acquire apparels business aimed } \\
\text { at sustainable apparels and textiles. }\end{array}$ \\
\hline
\end{tabular}




\begin{tabular}{|c|c|}
\hline $\begin{array}{l}\text { Promotional } \\
\text { Marketing }\end{array}$ & $\begin{array}{l}\text { 1. Advertise informational advertisements focusing the negative impacts of using } \\
\text { low organic content apparels. } \\
\text { 2. Develop a separation of CSR from Environmental activities to clarify the concept } \\
\text { for public. } \\
\text { 3. Use product information labeling on every apparel item and textile. } \\
\text { 4. Retailers shall have an audit history for providing traceable product } \\
\text { 5. Initiating awareness drives at consumer touch points (retail apparels stores), } \\
\text { handing out pamphlets in collaboration with the Sustainability Goals set by the } \\
\text { United Nations. }\end{array}$ \\
\hline Process Design & $\begin{array}{l}\text { 1. Textiles business should generate push demand dealings with local apparel } \\
\text { businesses to start using their sustainable product. } \\
\text { 2. Reengineer business processes to eliminate the silo mentality and sub- } \\
\text { optimization of departmental functions. } \\
\text { 3. Developing well ventilated and automated assisting machinery for stitching units. } \\
\text { 4. Establishing minimal waste in apparel manufacture, adopt best practices from } \\
\text { foreign apparel manufacturers. }\end{array}$ \\
\hline $\begin{array}{l}\text { People } \\
\text { Involvement }\end{array}$ & $\begin{array}{l}\text { 1. Promote modes of apparel disposal and set up collection centers for apparels to be } \\
\text { recycled. Beginning with denim recollection would be a start because textile } \\
\text { industry in Pakistan has the capacity for denim recycling. } \\
\text { 2. Initiate plastic recycling. Consumers availed collection spots for plastic } \\
\text { disposables outside dedicated apparels outlets. Textile mills in Pakistan also have } \\
\text { the capability for generating fibers from plastics. } \\
\text { 3. Provide retailers incentives to market products and benefits of the green products. } \\
\text { Gradual removal of cheap and non-traceable apparel items from the retail stores. } \\
\text { 4. Initiate merging of textile businesses and textiles institutes to enhance human } \\
\text { capital and public awareness on their purchase of commodities. } \\
\text { 5. Developing an industry for domestic fashion designers and boutique owners that } \\
\text { upcycle old garments. This will also generate opportunities for rural regions on a } \\
\text { mass scale rather than the premium products they are perceived as. } \\
\text { 6. Initiate mandatory cross-functional training of textiles and apparel business } \\
\text { employees on adopting to sustainable change. }\end{array}$ \\
\hline $\begin{array}{l}\text { Physical } \\
\text { Evidence of } \\
\text { Sustainability } \\
\text { Initiatives }\end{array}$ & $\begin{array}{l}\text { 1. Develop more LEEDs certified infrastructures for the milling and weaving } \\
\text { facilities in backward integration. } \\
\text { 2. Textile facilities should not be hidden behind a non-aesthetic industrial façade but } \\
\text { rather be a pride. } \\
\text { 3. Visible practices of water recycling, waste reuse, disposal and monitored } \\
\text { incinerators, layout, landscaping, atmosphere, labor protective clothing, treatment } \\
\text { plants, environmental management systems in the facilities. } \\
\text { 4. Developing alternative energy generation instead of coal powered electricity } \\
\text { generation. }\end{array}$ \\
\hline
\end{tabular}

\section{Conclusion}

Textile industry in Pakistan has been marred by hinderances in revenue generation from sustainable product, and market saturation of non-sustainable textiles. It was prevalent in the study that foreign textiles manufacturers moved towards sustainable green practices owing to consumer pressure to sustaining and protecting the environment. However, in Pakistan, it was the foreign consumer's pressure to adhere to green practices that began transforming the textiles industry to better standards and minimization of the human carbon footprint, but has generated little awareness or initiative in the Pakistani consumer to demand sustainable green product. Additionally, the costs incurred in sustainable textiles industry reflects in the high product pricing, further discouraging the local consumer that demands variety and affordability. As a result, the domestic markets deal with cheaper textiles sourced from India, China, and some premium products from Bangladesh, while the organic cotton apparels industry in Pakistan remains affordable to the upper class owing to this consumer segment's preference of high quality at higher cost. General preference of the Pakistani public is more focused towards unsustainable fast fashion because it impacts their income to a lesser extent, while satisfying their desire to keep up with the local fashion trends. In the sample selected of 6 companies, 3 had backward 
integrated their operations towards sustainable textiles production, while two were well on their way to backward integrate as well. So, contextually, it was understood that these companies began indigenously, and built their credentials to broadcast their competitive position globally, and then transcended borders to market sustainable premium product to high income countries for their financial sustainability. The motivator for quality sustainable textile export was the beneficial foreign exchange rate and foreign consumer awareness, while for domestic markets lack of consumer awareness acted detrimental to a shift to sustainable textile product market.

However, the Pakistani economy remains the biggest detriment to sustainable apparels while a motivator of affordable fast fashion's versatility. Hope for acceptance of sustainable production and consumption in textiles lies in enlightening the younger educated generation towards greener approaches to tackling the sustainability problem.

While this study concludes that there has been a lot of development in the textiles industry, it has benefited Pakistan only in terms of exports revenue, and the foreign apparels supply chains have mostly benefited from the offerings from Pakistani textiles. There is much potential if authorities like the Ministry of Textiles adopt the green marketing strategy as a statutory tool to make local apparel companies comply with sourcing of sustainable textile product, this would initiate a chain reaction from top to bottom and affect consumers at every stage of the apparel value chain to conform to a standard in responsible production and consumption of such textiles. The strategy would best develop as a resource constrained production of apparels with pull demand for more organic clothing that, in the long term will mature as positive influence on the textile and apparel situation of the country.

Author Contributions: Conceptualization, Hina Maryam \& Farhat Umar; Methodology, Hina Maryam \& Muniza Ifran; validation, Farhat Umar; formal analysis, Hina Maryam.; investigation, Hina Maryam; resources, Muniza Irfan.; data curation, Hina Maryam; writing — original draft preparation, Hina Maryam \& Muniza Irfan; writing-review and editing, Muniza Irfan; visualization, Hina Maryam.; Methodology supervision, Farhat Umer.; project administration, Farhat Umar. All authors have read and agreed to the published version of the manuscript.

Funding: This research was conducted as a final year thesis and was self-funded by the student researchers.

Acknowledgments: The researchers give thanks to their respective supervisor, Miss Farhat Umer of CSR, and co-supervisors: Prof Faheem Akhter (HOD MS), and Prof M. Waqas, at DHA Suffa University.

Conflicts of Interest: The authors declare no conflict of interest. All ethical considerations have been observed as per the respondents' request.

\section{References}

Arun Sharma, G. R. (2012). Resource-constrained product development: Implications for green marketing and green supply chains. Industrial Marketing Management, 599-608.

Asia Times Staff. (2019, March 5). South Asia has four most polluted countries. Retrieved from Asia Times: https://www.asiatimes.com/2019/03/article/south-asia-has-four-most-polluted-countries/

Asif, A. K. (2017). An Overview of Sustainability on Apparel Manufacturing Industry in Banladesh. Science Journal of Energy Engineering, 5(1), 1-12.

Braun, V. a. (2006). Using thematic analysis in psychology. Qualitative Research in Psychology, 3(2), 77-101.

cash, D. M., Clark, W. C., Alcock, F., Dickson, N. M., Eckley, N., Guston, D. H., . . . Mitchell, R. B. (2003). Knowledge systems for sustainable development. Cash, D. W., Clark, W. C., Alcock, F., Dickson, N. M., Eckley, N., Guston, D. H., ... \& Mitchell, R. B. (2003). KnowProceedings of the national academy of sciences, 8086-8091. 
Certification Standards Approved. (2019). Retrieved from Alkaram http://www.alkaram.com/corporate/cert.html

Chang, M. A. (2015). Apparel Manufacturers and the Business Case for Social Sustainability. The Journal of Corporate Citizenship(57).

Clark, W. C. (2016). Crafting usable knowledge for sustainable development. Proceedings of the National Academy of Sciences, 4570-4578.

Cradle to Cradle Products Innovation Institute. (2019). Retrieved from https://www.c2ccertified.org/get-certified/product-certification

Creswell, J. (2014). Qualitative Methods. In Research Design (pp. 183-213).

Crofton, F. (2000). Educating for sustainability: opportunities in undergraduate engineering. Journal of Cleaner Production, 379-405.

DAVID KIRON, N. K. (2013, February 5). THE INNOVATION BOTTOM LINE: Findings from the 2012 Sustainability \& Innovation Global Executive Study and Research Report. Retrieved from MIT Sloan Management Review: https://sloanreview.mit.edu/projects/the-innovation-bottomline/

Dawn. (2019, April 3). Pakistan among top 5 countries with highest mortality rate due to air pollution: study. Retrieved from Dawn: https://www.dawn.com/news/1473651

Gam, H. J., Cao, H., Farr, C., \& Heine, L. (2009). a sustainable apparel design and production model. International Journal of Clothing Science and Technology, 166-179.

Global Sustainability Standards Board. (2019). Retrieved from GRI Empowering Sustainable Decisions: https://www.globalreporting.org/standards/gri-standards-download-center/

Green Building Information Gateway. (2019). Retrieved from GBIG: http://www.gbig.org/places/809/activities

Hahn, N. P.-L. (2014). Fashion Design Industry Impressions of Current Sustainable Practices. The Journal of Design, Creative Process \& the Fashion Industry, 87-106.

Hall., T. F. (2011). The triple bottom line: What is it and How does it Work? Indiana Business Review, 86(1). Retrieved from Indiana Business Review.

Hing Kai Chan, H. H. (2012). Green marketing and its impact on supply chain management in industrial markets. Industrial Marketing Management, 557-562.

ISO 26000: Guide on Social Responsibility. (2018). ISO.

KENTON., M. G. (2019, June 25). Sustainability. Retrieved from Investopedia: https://www.investopedia.com/terms/s/sustainability.asp

LAKDAWALA, F. (2019, June 29). 6 Brands Paving The Way To Make Pakistan Green. Retrieved from MASHION: https://mashion.pk/6-brands-paving-the-way-to-make-pakistan-green/

Lele, S. M. (1991). Sustainable development: A Critical Review. World development , 607-621.

M. Ikram, P. Z. (2019). Do environmental management systems help improve corporate sustainable development? Evidence from manufacturing companies in Pakistan. Journal of Cleaner Production.

Magnus Boström, M. M. (2016). Introducing the Sustainability Challenge of Textiles and Clothing. Journal of Consumer Policy, 39, 367-375.

Marina Prieto-Carrón, A. C.-T. (2006). Critical perspectives on CSR and development: What we know, what we don't know, and what we need to know. International Affairs, 5(82), 977 - 987.

Muhammad Naveed Ikram, D. D. (2019). Effect of Green Supply Chain Management on Environmental Effect of Green Supply Chain Management on Environmental Industries in Pakistan. Social Science and Humanities Journal, 3(4), 1006-1019.

Nazan Okur, C. S. (2019). The Impact of Knowledge on Consumer Behaviour Towards Sustainable Apparel Consumption. Consumer Behaviour and Sustainable Fashion Consumption.

(2017, May). Pakistan National Action Plan on SDG 12. Ministry of Climate Change. GOP.

PakistanToday, P. (2019, April 14). Fashion Industry leading to environmental pollution, says business leader. Retrieved from Pakistan Today: https://profit.pakistantoday.com.pk/2019/04/14/fashionindustry-leading-to-environmental-pollution-says-business-leader/ 
Puigjaner., K. \&. (2018). Resource-Constrained Production Planning and Scheduling in Multistage Semicontinuous Process Industries. In Solving Large-Scale Production Scheduling and Planning in the Process Industries.

Redclift, M. R. (2006, January - June). SUSTAINABLE DEVELOPMENT (1987-2005) - AN OXYMORON COMES OF AGE. Horizontes Antropológicos, 12(25), 65-84.

S. Gunapalan, E. E. (2019). Factors Affecting on Job Performance of Employees in Apparel Industry: Special Reference to the Western Province, Sri Lanka. International Conference on Industrial Technology and Management.

Saeed, M. (2019, May). Creating a fashionably ethical industry. Retrieved from The News: https://www.thenews.com.pk/magazine/instep-today/473336-creating-a-fashionably-ethicalindustry

Scialabba, N. E.-H. (2013, April 29). Organic Agriculture's Contribution to Sustainability. Plant Management Network. Retrieved from http://www.fao.org/3/aq537e/aq537e.pdf

SEAQUAL. (2019). Retrieved from Together For A Cleaner Ocean: https://seaqual.org

Shen, B., Li, Q., Dong, C., \& Perry, P. (2017). Sustainability Issues in Textile and Apparel Supply Chains.

Stacey Frederick, J. D. (2019). Pakistan in the Apparel Global Value Chain. Duke Global Value Chains Center.

TAMMY L. LEWIS, C. R. (2019, October 18). Sustainability and Sustanable Development. Retrieved from Encyclopedia.com: https://www.encyclopedia.com/science/encyclopedias-almanacstranscripts-and-maps/sustainability-and-sustainable-development

(2015). Textile Policy (2014-19). Government of Pakistan, Ministry of Textile Industry.

(2019). The Sustainable Development Report. New York: Department of Economic and Social Affairs. Retrieved from https://unstats.un.org/sdgs/report/2019/The-Sustainable-Development-GoalsReport-2019.pdf

Usama Awan, A. K. (2019). Corporate Social Responsibility (CSR) Priorities in the Small and Medium Enterprises (SMEs) of the Industrial Sector of Sialkot, Pakistan. Corporate Social Responsibility in the Manufacturing and Services Sectors.

Yadlapalli, S. R. (2015). Sustainable Practices in Luxury Apparel Industry. Handbook of Sustainable Luxury Textiles and Fashion.

Zeeshan Mahmood, R. K.-e.-H. (2017). Why Pakistani Small and Medium Enterprises are Not Reporting on Sustainability Practices? Pakistan Journal of Commerce and Social Sciences, 11(1), 488-504. 


\section{Appendix A}

Figure 4. Sustainability Positioning Matrix (Yadlapalli, 2015).

\section{Appendix B}

Table 1. Attributes for sustainable matrix.

\begin{tabular}{|c|c|c|c|c|}
\hline Criteria & Ecopreneurs & Davids & Goliaths & $\begin{array}{l}\text { Sustainable } \\
\text { Entrepreneurship }\end{array}$ \\
\hline Quadrant & 4 & 3 & 2 & 1 \\
\hline Age & Relatively new & Relatively New & Older, Reigning & Older, Reigning \\
\hline Size & Small level & Small Level & Larger Level & Larger Level \\
\hline Objective & $\begin{array}{l}\text { Financial } \\
\text { stability is } \\
\text { dominating } \\
\text { function, social } \\
\text { and } \\
\text { environmental } \\
\text { are } \\
\text { complimentary } \\
\text { functions. }\end{array}$ & $\begin{array}{l}\text { Objectives } \\
\text { support 3PL } \\
\text { (people, planet, } \\
\text { profit) as equally } \\
\text { important to } \\
\text { economic } \\
\text { objectives. }\end{array}$ & $\begin{array}{l}\text { Financial stability } \\
\text { is dominating } \\
\text { function, social } \\
\text { and environmental } \\
\text { are } \\
\text { complimentary } \\
\text { functions. }\end{array}$ & $\begin{array}{l}\text { Objectives support } \\
\text { 3PL (people, } \\
\text { planet, profit) as } \\
\text { equally important } \\
\text { to economic } \\
\text { objectives. }\end{array}$ \\
\hline
\end{tabular}

Table 2: Information regarding sampled companies, their ages and relative sustainable scores. Depending on the polarity of the responses to the questionnaires in the contextual analysis, a 'yes' or 'no' were assigned to responses and their summation averaged by the total of 16 questions and displayed as score out of 100.

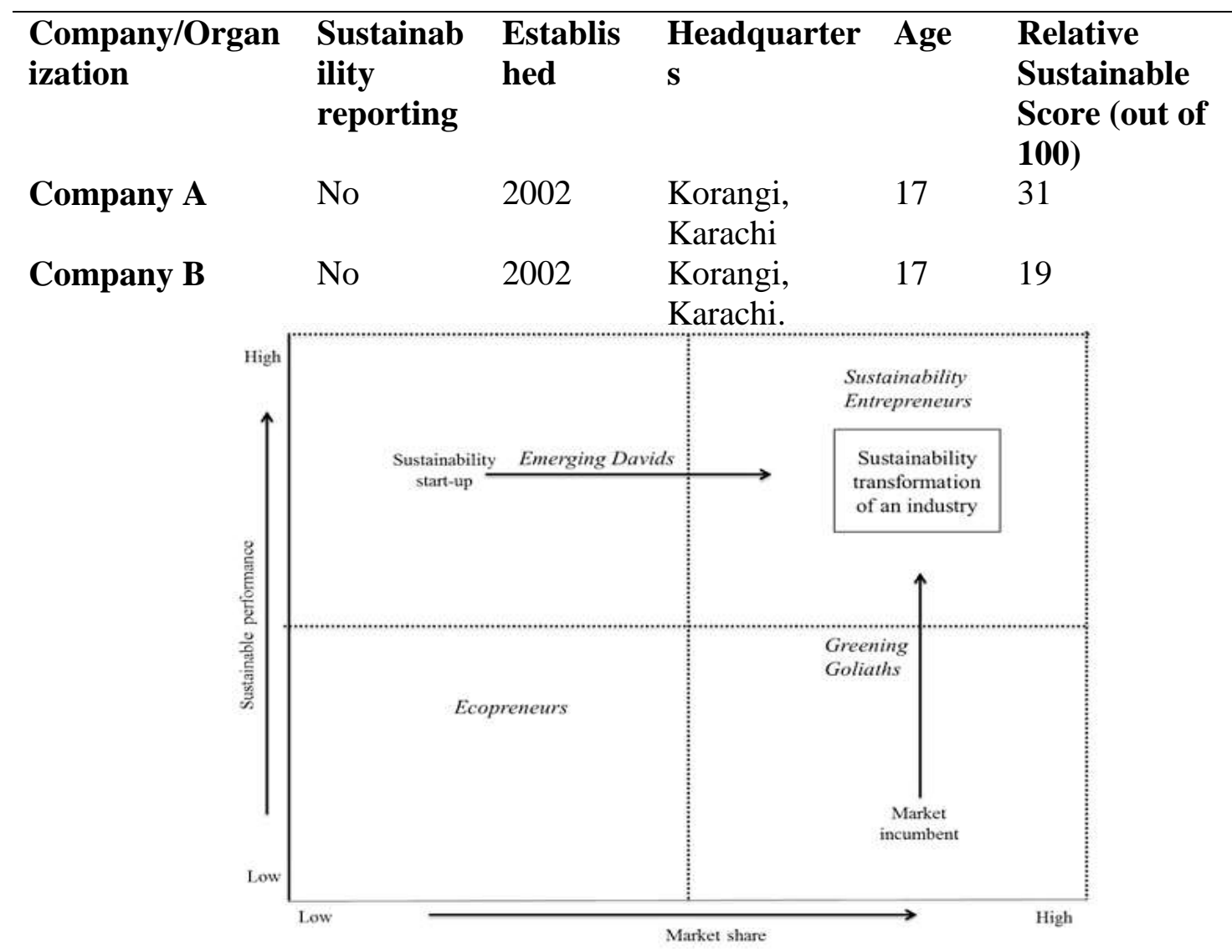




\begin{tabular}{lcclcc} 
Company C & Yes & 1983 & $\begin{array}{l}\text { Korangi, } \\
\text { Karachi. }\end{array}$ & 36 & 87 \\
Company D & No & 1988 & $\begin{array}{l}\text { SITE, } \\
\text { Karachi }\end{array}$ & 31 & 19 \\
Company E & Yes & 1986 & $\begin{array}{l}\text { Landhi, } \\
\text { Karachi. } \\
\text { SITE, } \\
\text { Karachi. }\end{array}$ & 33 & 62 \\
\hline
\end{tabular}

\section{Appendix C:}

Table 3: Questionnaire

\begin{tabular}{|c|c|c|c|}
\hline $\begin{array}{l}\mathrm{Sr} \\
\text { No. }\end{array}$ & Question & Category & $\begin{array}{l}\text { GRI } \\
\text { Reference }\end{array}$ \\
\hline 1 & $\begin{array}{l}\text { What is your understanding of } \\
\text { sustainable development, fast fashion, } \\
\text { and sustainable apparels? }\end{array}$ & - & - \\
\hline 2 & $\begin{array}{l}\text { Does your organization practice } \\
\text { transparent reporting with respect to } \\
\text { business activities? }\end{array}$ & - & - \\
\hline 3 & $\begin{array}{l}\text { Kindly introduce the organization with } \\
\text { respect to markets served, products } \\
\text { offered, your occupation and layout of } \\
\text { the business supply chain? }\end{array}$ & General Disclosure & 102 \\
\hline 4 & $\begin{array}{l}\text { What quality certifications has the } \\
\text { organization been certified with? }\end{array}$ & General Disclosure & 102 \\
\hline 5 & $\begin{array}{l}\text { Has there been a progress in adoption of } \\
\text { new management practices in the } \\
\text { organization? Elaborate. }\end{array}$ & $\begin{array}{l}\text { Management } \\
\text { Approach }\end{array}$ & 103 \\
\hline 6 & $\begin{array}{l}\text { What criteria is set for sourcing of fabric } \\
\text { from suppliers for apparel manufacture } \\
\text { in this company? Elaborate. }\end{array}$ & $\begin{array}{l}\text { Procurement } \\
\text { Practices } \\
\text { Supplier } \\
\text { Environmental/Social } \\
\text { Assessment }\end{array}$ & $\begin{array}{l}204 \\
308 / 414\end{array}$ \\
\hline 7 & $\begin{array}{l}\text { What are the materials used in apparel } \\
\text { manufacture of this company? (fresh, } \\
\text { recycled or reclaimed) }\end{array}$ & Materials & 301 \\
\hline 8 & $\begin{array}{l}\text { What apparel manufacture methods your } \\
\text { organization uses to reduce energy } \\
\text { consumption? }\end{array}$ & Energy & 302 \\
\hline 9 & $\begin{array}{l}\text { From where is water sourced for what } \\
\text { usage in the textile/ apparel manufacture } \\
\text { process? How is the waste dealt with? }\end{array}$ & $\begin{array}{l}\text { Water and Effluents } \\
\text { Effluents and Waste }\end{array}$ & $303 / 306$ \\
\hline 10 & $\begin{array}{l}\text { Does the manufacture process generate } \\
\text { harmful chemical emissions that the } \\
\text { organization monitors? }\end{array}$ & Emissions & 305 \\
\hline 12 & $\begin{array}{l}\text { What is the organization's attitude } \\
\text { towards environmentalism and customer } \\
\text { involvement? }\end{array}$ & $\begin{array}{l}\text { Environmental } \\
\text { Compliance } \\
\text { Local Communities }\end{array}$ & $307 / 413$ \\
\hline
\end{tabular}




\begin{tabular}{|l|l|l|l|}
\hline 13 & $\begin{array}{l}\text { Do you promote information regarding } \\
\text { your apparel products to consumers? } \\
\text { a) Recycling } \\
\text { b) Upcycling } \\
\text { c) Disposal and Impact } \\
\text { d) Other }\end{array}$ & $\begin{array}{l}\text { Marketing and } \\
\text { Labeling } \\
\text { Customer Health \& } \\
\text { Safety }\end{array}$ & 417 \\
\hline 14 & $\begin{array}{l}\text { Does your organization finance training } \\
\text { workshops on sustainability development } \\
\text { in business management? }\end{array}$ & $\begin{array}{l}\text { Training \& } \\
\text { Education }\end{array}$ & 404 \\
\hline 15 & $\begin{array}{l}\text { How do you deal with impacts of your } \\
\text { business activities on the local residents? }\end{array}$ & Local Communities & 413 \\
\hline 16 & $\begin{array}{l}\text { Does the organization have future plans } \\
\text { for developing more focus on } \\
\text { sustainability of apparel products } \\
\text { through experimenting with consumer } \\
\text { behavior? }\end{array}$ & $\begin{array}{l}\text { Management } \\
\text { Approach }\end{array}$ & 103 \\
\hline
\end{tabular}

